\title{
Maitreya and the Religious Situation according to Two Old Uighur Poems of Yuan Dynasty. Edition of SI 4485 and SI 4958
}

\author{
Peter ZIEME \\ Berlin-Brandenburg Academy of Sciences and Humanities \\ Berlin, Germany
}

DOI: $10.17816 / \mathrm{WMO} 77330$

\begin{abstract}
This paper offers the edition of SI 4485 and SI 4958, two manuscripts of the Old Uighur section of the Serindia Collection of the IOM written in alliterating verses. Their contents are praises on Maitreya, the future Buddha. The author tries to show why praises on Maitreya like the two presented here were written. He argues that it was to advocate the preservation of Buddhism through proving the superiority of the Maitreya cult over other religions in the current viral times of the Yuan.

Key words: Serindia Collection, Old Uighur, Maitreya cult, praises in.

For citation: Zieme, Peter. "Maitreya and the Religious Situation according to Two Old Uighur Poems of Yuan Dynasty. Edition of SI 4485 and SI 4958". Pis'mennye pamiatniki Vostoka, 2021, vol. 18, no. 3 (iss. 46), pp. 5-16 (in English). DOI: 10.17816/WMO77330

About the author: ZIEME Peter, Professor, the Berlin-Brandenburg Academy of Sciences and Humanities (Berlin, Germany) (ziemepet@gmail.com).
\end{abstract}

○ Zieme Peter, 2021

At the time when the religion of Islam was about to enter the oases of Xinjiang, the Uighur Buddhists developed a strong Maitreya cult and expressed in many writings, mainly in poems, their view that all people and all peoples should venerate Maitreya, the future Buddha. They promoted this cult by writing praises and other scriptures to keep alive the Buddhist faith and to strengthen the belief in Maitreya. The cult of the future Buddha Maitreya has a long tradition starting from the homeland of Buddhism and spreading to the modern regions where Mahāyāna teachings are en vogue today. In Central Asia we observe a special peak with the development of a voluminous scripture in Tokharian and Old Uighur under the name Maitreyasamitinātaka // Maitrisimit nom bitig ${ }^{1}$. Translated from the

\footnotetext{
${ }^{1}$ For studies in this field promoted by G.-J. Pinault and J.P. Laut see: Laut \& Wilkens 2017: 353-370 (Bibliography).
} 
Tokharian version, the Old Uyghur text gained great fame and was spread not only in the Turfan oasis in the 10th century, but also in the Qomul region from where a version dated to the year 1067 is attested by a large manuscript found near Tömürtü (Geng \& Klimkeit 1988). We have also testimonies of the Maitreya cult from paintings in several caves. Partly they follow models of Maitreyan paradises and Maitreya depictions in Dunhuang. Among Uighurs during the subsequent centuries up to the end of the Yuan dynasty a special genre was en vogue. These are texts of alliterating poems on Maitreya veneration featuring both main strands, the encounter with Maitreya on earth at the time when the future Buddha descends from the Tușita heaven or the rebirth in the Tușita heaven. Direct references can be found in a large number of colophons as well, but sometimes it is difficult to give a precise attribution of a certain praise. Several poems of this genre have been edited, but others are still waiting to be identified and edited among the unpublished materials. Previously, R.R. Arat started the work on Maitreya texts with a fragment of the Berlin Turfan Collection. ${ }^{2}$ In the subsequent years other fragments followed, including the longest Maitreya praise in alliterating verses in a miscellany manuscript ${ }^{3}$ and also shorter ones ${ }^{4}$, some of them re-edited by A. Yakup 5 . Fragments of the IOM Serindia Collection are mentioned in the newly published catalogue (Catalogue 2021).

Recently I had the honour to publish a newly identified fragment of a Maitreyan praise (SI 842 (Kr IV 304) + SI 4748 (O 87) + lacuna + SI 4068 (4bKr 77)) (Zieme 2021: 64-79). And in this sense this paper offers a further edition of two similar texts.

This is a modest contribution ${ }^{6}$ on the special occasion of celebrating the birthday of Irina F. Popova for her everlasting efforts to promote studies based on the materials kept in the largest treasure house of Oriental manuscripts and prints in the celebrated city of St. Petersburg.

\section{Manuscript I: SI 4485}

The manuscript that I would like to edit here has some very strange features. The vocabulary shows that several religions were around the Buddhists of Turfan. Although the manuscript is written in a cursive Uighur script type, one can easily read the text as long as it is well-preserved. At some places the script is torn and the paper is broken. This sheet comes from the finds of Krotkov and now belongs to the Serindia Collection of the IOM. It bears the code SI 4485. Probably the verso side was empty at the beginning, only afterwards some additional text sections were written, among the parts of visible lines one can observe at least two half sentences which are repetitions of the text of the recto side: yolčm bahšım and tüsürüg čäčäklig, but due to the glued cover nowadays these sections cannot be edited here.

The recto side has 45 lines from the main part of the poem, but beginning and end are missing because the sheet is damaged left and right. The poem is structured according to the usual way of strophical alliteration in four verses of a quatrain. The number of syllables varies, also in the usual system, between 5 (1:58) and 16 (1:58), but most verses have

\footnotetext{
${ }^{2}$ ETŞ Nr. 17.

${ }^{3}$ BT 3, 11. 761-1121.

${ }^{4}$ BT 13, text 19; Zieme 2006.

${ }^{5}$ Yakup 2015, chapters J and K. Cf. BT 47, mainly the section "Bausteine zu einer Sammlung von altuigurischen Maitreya-Hymnen (Kapitel J und K)".

${ }^{6}$ I express my gratitude to Marcel Erdal who kindly checked my paper and gave valuable information, especially on some spellings and the word sunčuk.
} 
$8(8: 58), 9(22: 58)$ or $10(12: 58)$ syllables, while 6 or 7 syllables are presented by 3 each, 11 syllables occur 4 times, and 12 syllables 3 times.

\section{The text of SI 4485 (Kr I 9)}

I.

[tö
[tö
[tö
02 töltäg-lig y[ ] $-\operatorname{lar}[:]$

II. [Description detail of the city of Ketumatī] tüšrök ${ }^{7}$ čäčäklig kapzı-1[arta]

[tözün] 04 yigit $^{8}$ kičig urılar

tükäl beš yüz yašlı[g] 05 kızlar birlä

tün kün adırtsız ögirgäylär

[In the] gardens (? $)^{9}$ of colourful flowers ${ }^{10}$

the [noble] heroes and youngsters

enjoy themselves day and night without distinction

with the five hundred year old girls ${ }^{11}$.

III. [Four Truths]

06 tüzülmišs ${ }^{12}$ inčgä oyunlarıg

tüzkäštürü 07 kirištürü ätizü

tört kertükä yarašı 08 takšutlar1 ${ }^{13}$

tözi agızlarıntın ketärmägäylär ::

Arranging $^{14}$ and introducing ${ }^{15}$

harmonious fine melodies for resounding ${ }^{16}$,

they let spring from their mouths nothing else than

poems corresponding to the Four Truths.

IV. [A description detail of the city of Ketumatī]

$09 \operatorname{arasiz}^{17}$ sansız ol tınl(1)glarnın

${ }^{7}$ Spelled twyswrwk.

${ }^{8}$ Spelled yykyd.

${ }^{9}$ As some parts of the letters are missing, the reading is not sure; even less its meaning. The most probable reading is q'pzy which looks similar to kapız "Schatulle, Sarg" (HWAU 332b), but should be a variant of haptse < Chin. hezi 盒子 “Gefäß, Schatulle, Behälter” (HWAU 278b). Note, though, that the context demands a larger space, perhaps a chamber or a room.

${ }^{10}$ ččck klyk can be read as čäčäklig "with flowers" or čäčäklik "flower garden".

${ }^{11}$ There is no direct connection, but in the Maitreya sūtra T. 455 it is said that the girls marry only at the age of five hundred years: T.XIV.0455.0426b05 女年五百歳 方乃作婚姻.

${ }^{12}$ Spelled twyswlmys.

${ }^{13}$ One expects rather an accusative suffix. Is here a mistake?

${ }^{14}$ The word tüzkäštürü is not recorded. It can be analyzed as follows: tüzük (OTWF 251) "well arranged" + $\ddot{a}-\check{s}$-tür-ü.

${ }^{15}$ For kirištür- cf. HWAU 383b.

${ }^{16}$ Spelled "dyzw.

${ }^{17}$ Before the beginning of the line one sees a + mark and the first part of the word was deleted. In another direction the margin was used for writing 'wytky ynkwq which one can read: üdki yaylok [1-hook missing] " $\ddot{u} d k i$ is wrong". In the deleted place one can see some remnants of these letters. Unfortunately, the corrected word is not clear. Since the verse begins with $a$-, one should expect ara, but the letters look rather like "'s. 
agır buyanları 10 -nı̣ tüšintä

adak basımı yerlärtä

altun 11 kümüš ök sačılgay

Through the fruit of the very good deeds

of the countless living beings

on the places wherever feet tread ${ }^{18}$

gold and silver are scattered.

In a description of the city of Ketumatī where Maitreya will appear one reads: (T.XIV.0453.0421b10) suowei jinyin zhenbao chequ manao zhenzhu hupo, ge sanzai di wuren xinglu 所謂金銀 珍 ${ }^{\mathrm{b} 11}$ 寶車渠馬瑙眞珠虎珀, 各散在地無人省録 "Namely gold and silver, precious jewels (like) agate, corals, pearls, amber are all scattered on the ground, but nobody takes care about it".

V. [Following the way of the ten karmapathas] alayın yıgayın tep ol tınl(1)g 12 -larnıy adak eligläri bolmadın adın amramakı $13 \mathrm{t}($ ä)nlämädin amuru on karmaputlarča ok 14 yorıgay-sizlär ::

Living beings wanting to take and collect it, if you have no feet and hands (to do it), without appreciating the love ${ }^{19}$ of others you shall always walk according to the ten karmapathas.

VI. [Dharmarāja] tüg tümän baglıg täyri 15 -lärnin töpölärintä kötürgülük tidimi 16 tört tugum beš ažunnuy umug1 tüzgärinč ${ }^{20} 17$-siz 1dok nom hanı

The diadem to wear by the gods

— belonging to many ten-thousands ${ }^{21}$ groups — on their heads

is the (token of) the inexhaustible holy Dharma King, hope of the four births and the five existences.

VII. [Gates of the 8 Noble Paths] törüsärsiz ol tušta :

18 törölüg tokulug balıkta tözün ${ }^{22}$ säkiz 19 yolnuy kapıg1 törttin yııaktın ačıl[ur]

If you appear at this time in the lawful beautiful city, the gates of the eight noble paths will be opened on all four sides.

\footnotetext{
${ }^{18}$ An interesting phrase is adak basiml.

${ }^{19}$ There is no accusative suffix!

${ }^{20}$ Spelled twysk'rynč.

${ }^{21}$ The syllable tüg occurs always before tümän in reduplication, cf. HWAU 769a.

${ }^{22}$ Spelled twyswn.
} 
In the third line we see a clear reordering of the term säkiz tözün yol "eightfold noble path" because of the alliteration. As a metaphor the "gate" is used here for the first time, as we can see from the collection of Buddhist metaphors (Kaygusuz 2021). The metaphorical gate is generally used in other contexts.

VIII. [Listening to the name of Maitreya destroys the kleśas] $20^{23}$ atı $^{24}$ kötrülmiš burhan maytre ${ }^{25}$ tep $\operatorname{atınızn1~}^{26} 21$ äšidmäktin ol tınl(1)glarnı̀ ugušı nizvane 22 -ları amrılıp ${ }^{27}$ ač1lgaylar nomlug közläri

By hearing your name - Buddha Maitreya the Exalted the passions of the entirety of living beings are calmed, their dharma eyes will be opened.

IX. [Knowledge leads to arhatship]

az $23-k(1) y a$ katıglanmakına ${ }^{28}$ nom tuyup

alku akıgları 24 alkınıp arhant kutılıg ${ }^{29}$ yeg tüšüg antača $25 \mathrm{k}(1)$ ya ok bulgaylar ::

Understanding the doctrine with a little effort, all (äsrava-)currents disappear, they will find at once the good fruit of arhatship.

X. [My master (= Maitreya) sits among gods and human beings]

bahšım yolčım ol üd 26 -tä bärü tep ${ }^{30}$

manuš ${ }^{31}$ tänri yalnoklug parišat kuvrag $27-$ nıy otırasınta ${ }^{32}$ bagdašınu oluru yarlıkap

My master, my guide! Since that time

— in the midst of the parișad ${ }^{33}$ multitudes

of human beings and gods -

you are sitting in paryanka position.

XI. [Pāramitā should spread everywhere] baš1 28 otırasi $^{34}$ üzlünčüsi $^{35}$

${ }^{23}$ Between lines 19 to 20 one phrase is inserted: atnıฤ buy-a süyäk(?).

${ }^{24}$ Spelled "dy.

${ }^{25}$ Spelled m[ ]ydry.

${ }^{26}$ Spelled "dynkyzny.

${ }^{27}$ Here we see the only serious infringement against the strophic alliteration. It can easily be saved by putting the verb at the beginning of the verse just as in the next verse: amrllp ol tınl(l)glarnıy ugušl nizvanelart.

${ }^{28}$ Spelled q'dyql'nm'qynk'. One should expect here a dative like emended to katıglanmakına.

${ }^{29}$ Spelled qwdy lyq.

${ }^{30}$ The word tep written between the lines was added.

${ }^{31}$ In HWAU 468a only manuši $<<$ Skt. manuşya.

${ }^{32}$ Spelled 'wdyr'synt'.

${ }^{33}$ SWTF III, 97b parișad "Versammlung, Gruppe".

${ }^{34}$ Spelled 'wdyr'sy.

${ }^{35}$ Spelled 'wyslwnčwsy. 
barčası yomkı ädgülüg

29 parimat $^{36}$ nomug tiläyü ${ }^{37}$

barčatın sınar lenhua ${ }^{38}$ ulal $^{39}$

Wishing the pāramitā-law

which is at the beginning, middle, and end

overall and entirely good;

everywhere lotus be spread ${ }^{40}$.

XII. [Monasteries of Kočo]

kutlug nom sizin ol üdtä ${ }^{41}$.

31 kočo kısıl bašdaš arayadan

kunsukmaksız 32 öglüg käd toyın

kut t(ä)ทrisintä külälgäy

The blessed dharma - yours at that time,

the foremost ${ }^{42}$ monasteries (of) the Kočo valley,

and the strong monks with a mind that cannot be stolen

will be praised by the god of fortune.

The kut tägrisi "God of fortune"43 appears here as a very high entity responsible for the growth and strength of Buddhism characterised as the teaching at a certain place under the care of a community of monks. The place referred to here are the monasteries in the Kočo valley.

XIII. [Quiet religious refuges]

33 gumura mačid manisdan

kurug sulaglar kiy

34 kulak tungučı bakgučı bolmadın

kopurga 35 örlätü enčikgäy ::

Cloisters ${ }^{44}$, mosques ${ }^{45}$, monasteries,

empty watercourses ${ }^{46}$, roads $^{47}$

no one who closes ears or looks around -

(only) owls ${ }^{48}$ will sound and surrender.

XIV. [After the descend of Maitreya even Arab kaliphs will surrender] surya-mandal kudı enmiš 36 täg

${ }^{36}$ Spelled p'rydm't.

${ }^{37}$ Spelling is not clear.

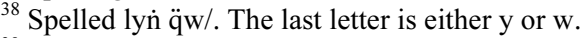

${ }^{39} b(a) r \check{c} a[$ ], all other words of this line are dubious, some of them may be regarded as being deleted. Moreover, the paper is broken. Between this and the following line the verse was apparently repeated as given above.

${ }^{40}$ The spelling of the last word is not clear, ulal is only a guess.

${ }^{41}$ Spelled 'wyt t'.

${ }^{42}$ HWAU 148 b.

${ }^{43}$ HWAU 429b.

${ }^{44}$ Probably read gumra, cf. HWAU 275 b gumra < Syr. 'wmr' "monastery".

${ }^{45}<$ Ar. $m s \grave{g} d$ "mosque".

${ }^{46}$ sulag $<$ suvlag.

${ }^{47} k l y<$ chin. jie HWAU 349 (kay and kly).

${ }^{48}$ Jens Wilkens now reads koburga (HWAU 388a). 
surtok $^{49}$ bo yertinčükä ensärsiz

37 sultan $^{50}$ bašlap kalipalar

soka sizinä inangay 38 -lar

When you, like the sun mandala ${ }^{51}$ descends,

quickly descend into this world,

the khalifs ${ }^{52}$ headed by the sultan ${ }^{53}$

will directly believe in you.

XV. [Muslims and others will become Buddhist followers]

sundar ${ }^{54}$ täg burunlug musurmanlar

suvtın 39 arınmak umunčluglar

sunčuk k1lur törölüg urug ${ }^{55}$

soka burhan nomlug 40 bolgay-lar ::

The Muslims with noses like sundar(?),

those who hope to be cleansed by water,

the progeny with the tradition of making mats(?),

will be those who immediately adopt the Buddha's teaching.

In this stanza members of non-Buddhist religions are mentioned by recalling special symbols or features. The first verse ascribes Muslims having noses like sundar, the easiest possible reading for swnd'r. As a Turkic word cannot be found, it probably is derived from Skt. sundara "beautiful" which i.a. is also a name of a gandharva. One cannot be sure that this gandharva had a remarkable nose to be used as a metaphorical medium ${ }^{56}$. On the other hand, the same letters can also be read as šundar from Skt. sunḍ̂ara "the trunk of a young elephant" (MW 1081c.). In any case, if this comparison is correct, it is meant in a very discriminating way. Although this spelling breaks the norm of the stropical alliteration, it is more probable to adopt in this verse as a metaphor. But if again one thinks of a Turkic word, one can refer to Kırgiz sono // sonor "duck, drake" (Judachin 653). A metaphorically used similar expression is given by Meninski with his patka burunlu (Meninski 1680: 5972) for a person with a nose like a duck's beak. I follow here the nose study of A. Tietze (Tietze 1983: 121) who suggests that this expression rather corresponds to Persian pūč-binn "large or hook-nosed" (Steingass 1892: 259a). But this, too, remains dubious because of the difficult relation of sondar to sonor.

The second verse is also enigmatic. If one regards it as a circumscription for baptism, this verse refers to Christians who are often called as people of baptism.

The third verse refers to a community whose followers make mats used for praying if the reading sunčuk ${ }^{57}$ is correct. The other spelling sučuk is less probable. The modern Turkish word sucuk as a special kind of sausage is very common and is known from Ottoman sources (Meninski 1680: 2559).

\footnotetext{
${ }^{49}$ surtduk $<$ surt + ok.

${ }^{50}$ Spelled swld'n.

${ }^{51}$ suryamantal < skt. sūryamandala, cf. HWAU 632b.

${ }^{52}$ kalipa [ä'lyp'] < Ar. halīfa, HWAU 323b.

${ }^{53}$ suldan $<$ Ar. sulțān.

${ }^{54}$ Spelled swnd'r.

${ }^{55}$ The spelling is not clear.

${ }^{56}$ In the episode of the Gandharva Sundara which is chapter 24 of the English translation of the Skanda Purana that gandharva's nose is not mentioned, thus it is not sure that the gandharva is meant here.

${ }^{57}$ HWAU 631a.
} 
XVI. [People serving in the Mahāyāna are dressed modestly]

l-a buyum ešgirti ${ }^{58}$.

tärz nom 41 -lug luu-kin

taišinta tapıglıg

1-a ešgirti kara ken tonlug ${ }^{59}$

Silk $^{60}$ coverings $^{61}$ or brocade ${ }^{62}$

Luukin with false teaching.

Those who serve in the Mahāyāna -

with black wide clothes of silk and brocade.

In this stanza the author gives a comparison between non-Buddhist and Mahāyāna teaching. The representative of the "wrong law" is $l w w k y n=L u u k i n$ in which one can see a phonetical adaptation of Chinese laojun 老君, another name of Laozi ${ }^{63}$. In the Alphabetical Poem the Uighur form is lavkun which better fits to the supposed origin than luukin (Zieme 1991: 276). Therefore the identification is not absolutely sure.

XVII. [Not discernible as verses]

käpäk säpäk ${ }^{64} 42$ küsüšlüglär sizin-lär

kamugun yomkı 43 /////w tar-ka tarın-takı yašı kudulu

$\mathrm{k}(\mathrm{a}) \operatorname{rg}(\mathrm{a}) \mathrm{tm} ı$ š 44 [ ]ičim sizijä ök.

45[

]r

Those who have the wish for käpäk säpäk(?), you altogether

...his tears in ... were flowing

cursed my ... to you!

\section{Manuscript II: SI 4958 verso}

The second poem is written on the verso side of SI 4958 ( $\mathrm{Kr}$ I 14). Its recto side is part of a Chinese scroll of the Miaofa lianhua jing 妙法蓮華經 (T.IX.262.30a29-b13). The poem is written in a question - answer style. It culminates in expressing the wish to be born in the Tușita heaven in the presence of Maitreya.

\section{The text of SI 4958 verso}

I. [A kind of excuse]

01 munı birlä bitisär bolur mu tep ildim

Is it right that I attached here what I write?

\footnotetext{
${ }^{58}$ Spelled 'yskyrdy.

${ }^{59}$ This line is written between the lines. The last two words are unclear.

${ }^{60}$ la < Chin. luo "silk" (HWAU 449b).

${ }^{61}$ Spelled pwywm = buyum which is known from modern Uighur as a general term for "article, things, goods" (Schwarz 1992: 88a). However, one can see one more hook in the word, which allows us to transliterate pwyrwm $=$ *bürüm a non-attested derivate from bür- "to twist, wind round, screw together" (ED 355a).

${ }^{62}$ ešgirti "brocade" (HWAU 264a).

${ }^{63}$ Cf. HWAU 452a lavkun < chin. laojun 老君 “Laozi”.

${ }^{64}$ This line is written between the lines. The last two words are unclear.
} 
II. [Author's introduction]

02 arok tilkükä okšatı ${ }^{65}$.

atıkmıš $^{66}$ mürki kulutnuy.

adınčig 1dok baši ${ }^{67}$ bo

03 mant(a)lmallıg urukka ${ }^{68}$.

I am the stupid one known to be

'similar to a tired fox',

whose wonderful holy head

is for this loop of a round garland.

If the explanation of mant(a)lmallig as "having a mandalamālä" is correct, it is a qualifying attribute to uruk "lasso, rope". The term consists of mandala "round, circle" and māla "garland", for what usually mālā (Saunders 1960: 174-177) itself is used.

III. [Reasons of the author's training] agtınu $^{69}$ tıdınu täginmäkim ärsär.

avantlıg 04 tıltaglıg täginür

My humbly ascending und self-control

has grounds and reasons.

IV. [Question about the reasons] nätägin ${ }^{70}$ tep tesär :.

kim ol

Which?

(They are) as follows.

V. [The Buddha's teaching]

kertütin kälmiš 05 burhan bahšılıg.

kesare arslan hanının.

kinayan mahayan tep kükülmiš

06 ken tärin yörüglüg taluyına.

It is the ocean of broad and deep explanations

praised as hinayāna and mahāyāna

of the kesarin lion king,

the Buddha master Truly Come.

VI. [Teaching as ship and bridge]

kertgünmäk süzülmäk ukmak 07 -lıg.

kemi köprüg üzä kölünüp.

kizläglig $^{71}$ nomlug ärdinilärig 08 aldač1.

kiši körklüg kinšuk ärdini ::

\footnotetext{
${ }^{65}$ Or: ogšatı (HWAU 503b).

${ }^{66}$ Spelled "dyqmys.

${ }^{67}$ Spelling is not clear.

${ }^{68}$ It seems that the scribe did not use an aliph before w-, generally one can say that in this manuscript the aliph hook before vowels is very small.

${ }^{69}$ Spelled "qdyniw.

${ }^{70}$ Spelled n'd'kyn.

${ }^{71}$ Spelled kysl'klyk.
} 
Using the ship and the bridge

of belief and insight for devoting

the kimsinka ${ }^{72}$ jewel in the shape of a human being

who takes the jewels of the secret dharma.

VII. [The Buddha who sowed the seed of salvation] ugan[lar] aržisı burhan bahšıtın

09 okadıp kalmıš beš ažun tınl(1)glarnı̣ umugı.

[ogu]l eligi maytreta 10 ozguka $^{73}$ urug äkmiš.

on karmapat küzädür ${ }^{74}$ up[a]se atl(1)g ::

Hope of the living beings of the five existences who came late

(to meet) the Buddha master, the rsși of the mighty ones ${ }^{75}$.

Who has sown the seed for the salvation by the prince Maitreya

the one who is called upāsaka protecting the ten karmapathas.

VIII. [True belief; wish to be born in Tușita] tuyunmıšlar 11 burhan bahšının nomınta. turıtmaksız bäk katıg ${ }^{76}$ süzök kertgünč köyül 12 -lüglär. tugmıš kadaš birlä birgärü.

tušit ordota maitre bodis(a)t(a)v 13 [ü]skintä tuggalı küsüšlüg.

Those who have insight have an irreversible firm true belief in the teachings of the Buddha master.

Together with the family members

they have the wish to be born in the presence of Maitreya Bodhisattva in the Tușita palace.

IX. [Laymen belonging to the author's family] turmıš upase kutlug niran kurtga ${ }^{77} 14$ asan birlä inčă tep sözläšü täginmišlär ::

We, the layman Turmıš, Kutlug Niran ${ }^{78}$ and Kurtga Asan, have agreed on it.

$\mathrm{X}$. [Life goes on] yuylaguča ädkä tavar 15 -ka.

yok yitmäz $\mathrm{z}^{79}$ ymä ärmäz biz.

yollug yolsuz kalganka.

yomkımız $16-[\mathrm{n}] 1$. yuplap yorır biz ::

As long as we can make use of materials.

it is not that we do not die nor that we are not.

For all those who remain with a way or without a way:

using all of us we are living.

${ }^{72}$ kyn்swq $=$ kinšuk $<$ Skt. kimśuka $($ HWAU 382a).

${ }^{73}$ Spelled wsqw-q'.

${ }^{74}$ Spelled kwys'dwr.

${ }^{75}$ Spelled 'wq'n[///] "rsy sy = uganlar aržiss "Seher der Göttlichen" (HWAU 787b) < Skt. devārsṣi, epithet of the Buddha.

${ }^{76}$ Spelled q'dyq.

${ }^{77}$ Spelled qwrdq?

${ }^{78} \mathrm{Spelled}$ n/yrin(?). One possible reading is Niran, but several others can be suggested.

${ }^{79}$ Spelled yydm'z. 


\begin{tabular}{ll}
\multicolumn{2}{l}{ Abbreviation } \\
BT 3 & Tezcan 1974 \\
BT 13 & Zieme 1985 \\
BT 47 & Zieme 2020 \\
ED & Clauson \\
ETŞ & Arat \\
HWAU & Wilkens 2021 \\
MW & Monier Williams \\
OTWF & Erdal 1991 \\
STWF & Sanskrit-Wörterbuch
\end{tabular}

\section{References}

Arat, Reşid Rahmeti 1965 - Eski Türk Şiiri. Ankara: Türk Dil Kurumu, 1965 (in Turkish).

Catalogue of the Old Uyghur manuscripts and blockprints in the Serindia Collection of the Institute of Oriental Manuscripts, RAS. Vol. 1. Tokyo: The Toyo Bunko, 2021 (in English).

Clauson, Gerard 1972 - An Etymological Dictionary of Pre-Thirteenth-Century Turkish. Oxford: The Clarendon Press, 1972 (in English).

Erdal, Marcel 1991 - Old Turkic Word Formation. A Functional Approach to the Lexicon, I-II. Wiesbaden: Harrassowitz, 1991 (in English).

Geng, Shimin \& Klimkeit, Hans-Joachim 1988 - Das Zusammentreffen mit Maitreya. Die ersten fünf Kapitel der Hami-Version der Maitrisimit. In Zusammenarbeit mit Helmut Eimer und Jens Peter Laut. I-II. Wiesbaden: Harrassowitz, 1988 (in German).

Judachin, K.K. 1965 - Kirgizsko-russkii slovar' [Kirgiz-Russian Dectionary]. Moscow: Sovetskaia Enciklopediia, 1965 (in Russian).

Kaygusuz, Arzu 2021 - Buddhistische Bildersprache in alttürkischen Texten, Eine literaturwissenschaftliche und philologische Analyse. Wiesbaden: Harrassowitz, 2021 (in German).

Laut, Jens Peter \& Wilkens, Jens 2017 - Alttürkische Handschriften Teil 3: Die Handschriftenfragmente der Maitrisimit aus Sängim and Murtuk in der Berliner Turfansammlung. Stuttgart: Steiner Verlag, 2017 (VOHD XIII, 11) (in German).

Meninski, F. à Mesgnien 1680 - Thesaurus Linguarum Orientalium - Lexicon Turcico-ArabicoPersicum. Wien: Typograheo Orientali Schigliano, 1680 (in Latin).

Monier-Williams, M. 1899 - A Sanskrit-English Dictionary. Oxford: Motilal Banarsidass Publishing House (reprint), 1899 (in English, Sanskrit).

Sanskrit-Wörterbuch der buddhistischen Texte aus den Turfan-Funden und der kanonischen Literatur der Sarvāstivāda-Schule, begonnen von E. Waldschmidt, hrsg. von H. Bechert. Göttingen: Vandenhoeck \& Ruprecht, 1973 (in German).

Saunders, E. Dale 1960 - Mudrā. A Study of Symbolic Gesture in Japanese Buddhist Sculpture. New York: Pantheon Books Inc, 1960 (in English).

Schwarz, Henry G. 1992 - An Uighur-English Dictionary. Bellingham. Washington: Center for East Asian Studies. Western Washington University, 1992 (in English).

Steingass, F. 1892 - A Comprehensive Persian-English Dictionary. Oxford: Librairie du Liban Publishers (reprint) 1892 (in English).

Tezcan, Semih 1974 - Das uigurische Insadi-Sūtra. Berlin: Akademie Verlag, 1974 (Berliner Turfantexte 3) (in German).

Tietze, Andreas 1983 - "Türkisch burun ,Nase'. Versuch einer phraseologischen Monographie". Wiener Zeitschrift für die Kunde des Morgenlandes, 1983, vol. 75, pp. 99-156 (in German).

Wilkens, Jens 2021 - Handwörterbuch des Altuigurischen. Altuigurisch-Deutsch-Türkisch. Eski Uigurcanin El Sözlüğü. Eski Uigurca-Almanca-Türkçe. Göttingen: Universitätsverlag, 2021 (in German). 
Yakup, Abdurishid 2015 — 阿不都热西提 - 亚库甫 [Gudai weiwuer yu zanmeishi he miaoxiexing yunwen de yuwenxue yanjiu] 古代维吾尔语美诗和描写性韵文旳语文学研究 [Old Uighur Hymns, Praises, Blessings and Descriptive Poems]. Shanghai: Shanghai Chinese Classics Publishing House, 2015 (in Chinese).

Zieme, Peter 1985 - Buddhistische Stabreimdichtungen der alten Uiguren. Berlin: Akademie-Verlag, 1985 (Berliner Turfantexte 13) (in German).

Zieme, Peter 1991 - Die Stabreimtexte der Uiguren von Turfan und Dunhuang. Studien zur alttürkischen Dichtung. Budapest: Akadémiai Kiadó, 1991 (in German).

Zieme, Peter 1994 - "Zum Maitreya-Kult in uigurischen Kolophonen”. Rocznik Orientalistyczny 49, 1994, pp. 219-230 (in German).

Zieme, Peter. "La poésie en turc ancien d'après le témoignage des manuscrits de Turfan et Dunhuang". In: Comptes Rendus de l'Académie des Inscriptions \& Belles-Lettres. Paris, 2006, pp. 1145-1168 (in French).

Zieme, Peter 2013 - "Ein alttürkischer Maitreya-Hymnus und mögliche Parallelen". In: Die Erforschung des Tocharischen und die alttürkische Maitrisimit. Symposium anlässlich des 100. Jahrestages der Entzifferung des Tocharischen. Berlin, 3. und 4. April 2008. Turnhout: Brepols, 2013, pp. 403-416 (Silk Road Studies. XVII) (in German).

Zieme, Peter 2020 - Uigurorum veterum fragmenta minora. Turnhout: (Berliner Turfantexte 47, including text 12: Altuigurischer Lobpreis auf Maitreya in Versen, die in der Anrufung, die Nöte des Uigurischen Reichs zu lindern, kulminieren). Turnhout: Brepols, 2020 (in German).

Zieme, Peter 2021 - "Vnimaite Nastavnikam!" Drenveuigurskoe Voskhvalenie Buddy Maitreia [«Listen to the Masters!». An Old Uighur Maitreya Praise]. Pis 'mennye pamiatniki Vostoka, 2021, vol. 45, no. 2, pp. 64-79 (in Russian).

\title{
Майтрея и религиозная ситуация по двум староуйгурским стихотворениям периода династии Юань. Списки SI 4485 и SI 4958
}

\author{
Петер ЦИМЕ \\ Берлин-Бранденбургская Академия наук \\ Берлин, Германия
}

Статья поступила в редакцию 10.05.2021.

Аннотация: В статье представлены две рукописи на староуйгурском языке из сериндийской коллекции ИВР РАН, хранящиеся под шифрами SI 4485 и SI 4958. Тексты написаны стихами с начальной аллитерацией и посвящены Майтрее, Будде будущего. Содержание текстов воспевания Майтреи свидетельствует о том, что в Центральной Азии буддисты периода династии Юань всячески пытались продемонстрировать приоритет культа Майтреи над всеми другими религиями, распространяемыми в этом регионе. В статье предлагается комментированный перевод обоих текстов на английский язык.

Ключевые слова: ИВР РАН, сериндийская коллекция, староуйгурский язык, культ Майтреи.

Для цитирования: Zieme P. Maitreya and the Religious Situation according to Two Old Uighur Poems of Yuan Dynasty. Edition of SI 4485 and SI 4958 // Письменные памятники Востока. 2021. T. 18. № 3 (вып. 46). С. 5-16 (на англ. яз.). DOI: 10.17816/WMO77330

Об авторе: ЦИМЕ Петер, профессор Берлин-Бранденбургской Академии наук (Берлин, Германия) (ziemepet@gmail.com). 